\title{
华北地块南缘钼矿床黄铁矿流体包裹体氦、氞同位素 体系及其对成矿动力学背景的示踪
}

朱赖民，张国伟，郭波，李制

\author{
西北大学地质学系, 大陆动力学国家重点实验室, 西安 710069 \\ E-mail: zhulaimin@nwu.edu.cn
}

2008-08-18 收稿, 2008-12-05 接受

国家重点基础研究发展计划(编号: 2006CB403502)、国家自然科学基金(批准号: 40872071)、中国科学院矿床地球化学国家重点实验室项目 (批准号: 20060)、陕西省教育厅基金(批准号: 07JK414)和南京大学内生成矿作用国家重点实验室项目(批准号: 14-08-1)资助

摘要 以华北地块南缘东秦岭钼矿带的金堆城、东沟、石家湾和三道庄等钼矿床为例, 报 道了东秦岭钼矿带成矿流体氦和氩同位素组成, 通过氦、氞和铅同位素的综合研究, 探讨 了成矿流体来源、演化及其与秦岭造山带中-新生代陆内碰撞造山过程的耦合关系. 华北 地块南缘东秦岭钼矿带钼矿床黄铁矿流体包裹体的 ${ }^{3} \mathrm{He} /{ }^{4} \mathrm{He}$ 比值在 1.38 3.64 Ra 之 间, ${ }^{40} \mathrm{Ar} /{ }^{36} \mathrm{Ar}$ 比值为 $295.68 \sim 346.39$, 指示成矿流体系由不同性质和组成的两个端元流体 混合而成, 即与壳幔混合成因斑岩体同源的高温深源流体和富含地壳放射成因氦但具有 空气氩同位素组成特征的低温大气降水. 东秦岭钼矿带矿床铅同位素组成、斑岩体和区 域地层岩石含矿性资料共同揭示, 矿床成岩成矿物质来自深部, 为下地壳和上地幔混合 源. 华北地块南缘钼矿床的形成可能与秦岭造山带碰撞造山后的陆内造山和伸展过程相 伴的壳幔相互作用有关, 与钼矿化有关的斑岩属同熔型花岗岩类, 而非简单的陆壳重熔 型花岗岩类或 $S$ 型花岗岩, 因此具有深刻的深部和区域地球动力学背景.
关键词

华北地块南缘钼矿床

黄铁矿流体包裹体

氦、氩和铅同位素

地幔流体

成矿动力学背景
秦岭造山带由 2 条主缝合带和由其分划的 3 个地 块组成, 即由商丹和勉略缝合带、华北地块南缘、秦 岭微地块和扬子地块北缘组成 ${ }^{[1 \sim 4]}$. 华北地块南缘是 秦岭造山带岩石圈现今三维结构的基本要素和重要 组成部分, 其分布范围限定在天水-宝鸡-潼关-渑池宜阳-鲁山-午阳-线 $\left(\mathrm{F}_{1}\right)$ 以南(图 1)和洛南-㴒川断裂 $\left(\mathrm{F}_{2}\right)$ 以北区间。该构造单元分布着华北地块南缘著名的 东秦岭钼矿带. 东秦岭钼矿带目前控制储量达 500 万 吨, 已超过美国Climax-Henderson斑岩钼矿带而成为 全球第一大钼矿带 ${ }^{[5]}$. 该钼矿带西起陕西省的金堆城 地区，东至河南省栾川南泥湖-三道庄-上房沟、嵩县 雷门沟地区，产出了金堆城、石家湾、南泥湖、三道 庄、上房沟、东沟超大型钼矿床和雷门沟等 10 余个
大型钼(铇)多金属矿床，钼储量约占全国总储量的 $52 \%$. 华北地块南缘钼矿产于我国大陆内部碰撞造山 带中, 明显不同于产于洋-陆俯冲造山带的ClimaxHenderson钼矿带, 是研究大陆内部成岩成矿作用, 发展大陆动力学与大陆成矿理论的理想研究对象 ${ }^{[6]}$, 对研究中国大陆构造、资源和环境效应具有重要理论 和实际意义 ${ }^{[2 \sim 4]}$. 因此, 东秦岭钼矿带的成矿地球动 力学背景久为国内外学者所共同关注, 迄今不少学 者对东秦岭钼矿带的矿床时空分布、成矿物质来源、 构造环境、成岩成矿年龄、分类及矿化特征等进行了 深入探讨 ${ }^{[732]}$. 但是, 目前有关华北地块南缘构造单 元中的陆内俯冲带的俯冲深度和形成动力学背景仍 存在不同的认识. 张国伟等学者 $\stackrel{[2 \sim 4,33]}{ }$ 根据反射地震 


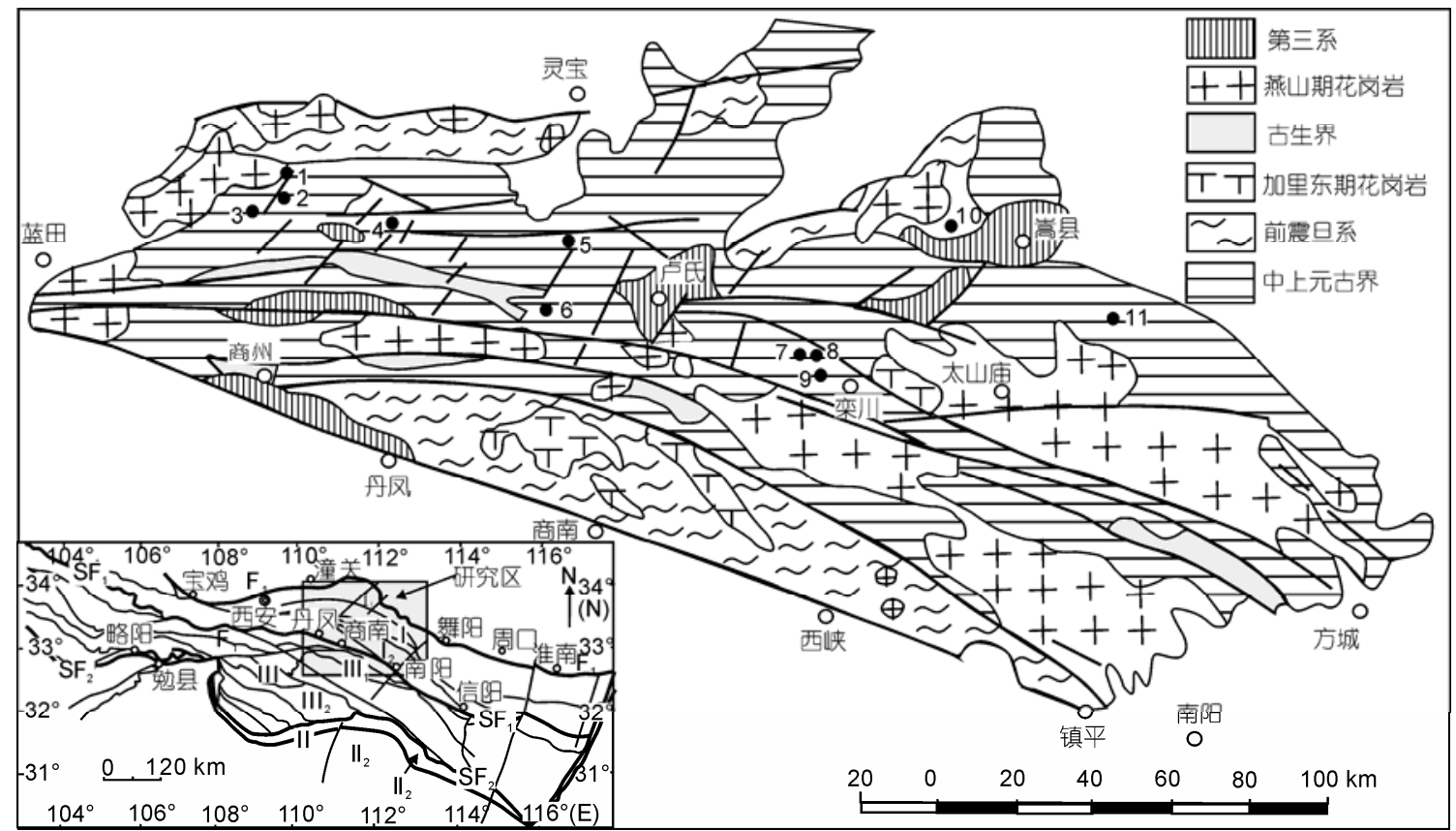

图 1 华北地块南缘东秦岭钼矿带地质略图

据文献[2,20]改编. 1, 黄龙铺; 2, 石家湾; 3, 金堆城; 4, 木龙沟; 5, 银家沟; 6, 夜长坪; 7, 上房沟; 8, 南泥湖; 9, 三道庄; 10 , 雷门沟; 11 , 东沟. I, 华北板块南部; $F_{1}$, 秦岭造山带现今北界, 华北地块南部巨型陆内俯冲带; I ${ }_{1}$, 秦岭造山带北缘逆冲推覆构造系; I ${ }_{2}$, 北秦岭 迭瓦状逆冲推覆构造系; $\mathrm{SF}_{1}$, 商丹古缝合带; II, 扬子板块北部; II 1 , 秦岭造山带前陆逆冲断裂袺皱带; II 2 , 秦岭-大别南缘逆冲推覆 系前锋断裂褶坡带; III, 秦岭微板块; $11 I_{1}$, 南秦岭北部逆冲推覆构造系(原南秦岭北部断陷带); $1 I_{2}$, 南秦岭南部逆冲推覆构造系(原南 秦岭南部隆起带); $\mathrm{SF}_{2}$, 勉略古缝合带

为主的综合地球物理探测和地质研究已经证实, 秦 岭现今北界存在华北地块南部自北向南向秦岭的巨 型陆内俯冲带, 俯冲深达Moho面以下, 具有深刻的 深部和区域地球动力学背景, 与之相伴在中上地壳 发育自南向北的逆冲推覆构造带, 成为秦岭与华北 地块间中新生代重要陆内构造, 华北地块南缘在中 新生代经历从深部地幔动力学的最新调整到上部地 壳响应所发生的壳幔相互作用过程 ${ }^{[24]}$, 由此推断华 北地块南缘钼矿带属于同熔型花岗岩类诱发的斑岩 型钼矿化, 而非陆壳重熔型花岗岩类或 $S$ 型花岗岩 [7,21]. 安三元等人 ${ }^{[27]}$ 明确提出斑岩的岩浆源应为下地 壳, 而不是上地幔. 陈衍景等人 ${ }^{[5,6]}$ 系统总结了岩体 的锶氧同位素特征, 并结合成岩构造背景、岩石矿物 学和地球化学特征及区域地球物理资料, 认为浅成 斑岩与深成花岗岩基同属中生代华南与华北古板块 碰撞造山过程发育的改造型花岗岩类或大陆地壳重 熔花岗岩类, 主要来自东秦岭陆壳板片 $\mathrm{A}$ 型俯冲引发 的陆壳重熔作用, 成岩成矿的物源区不可能是地幔 和俯冲洋壳, 而是大陆地壳. 孙晓明等人 ${ }^{[17]}$ 的研究表
明, 东秦岭钼矿带存在改造型及同熔型两类花岗岩, 前者(深成花岗岩基)为上地壳地层重熔形成改造型 花岗岩, 后者(浅成斑岩)为下地壳及上地幔分熔形成 的同熔型花岗斑岩. 由此可见, 确定华北地块南缘 中、新生代陆内俯冲作用过程发生的深部地球动力学 背景和澄清陆内俯冲作用过程中有无幔源组分加入, 目前仍是确定华北地块南缘构造单元属性和形成演 化的关键科学问题, 中国东部岩石圈的巨厚减薄使 得对上述有争议问题的研究显得更有科学意义. 成矿 系统的发育和保存要求苛刻的地质条件, 矿床是研 究大陆动力学或岩石圈构造演化的理想探针 ${ }^{[34,35]}$, 因此分布于华北地块南缘的斑岩型钼矿床记录着该 构造单元岩石圈演化和壳-幔作用的重要信息, 而无 疑成为研究秦岭造山带构造单元属性和华北地块南 缘岩石圈构造演化的理想研究对象. 近 20 年来, 稀 有气体同位素体系被广泛应用于地质过程的地球化 学示踪研究. 由于不同来源地质体的稀有气体同位 素组成差异很大, 且稀有气体同位素组成在水-岩反 应等地质过程基本保持不变，因此稀有气体同位素 
特别是 $\mathrm{He}$ 和 $\mathrm{Ar}$ 同位素在研究成矿流体来源、演化和 壳一幔相互作用机制等研究中取得了长足的进展 ${ }^{[36 ~ 64]}$. $\mathrm{He}$ 和 $\mathrm{Ar}$ 在大气降水、地幔和地壳中具有极不相同的 同位素组成, 尤其是地壳氦 $\left({ }^{3} \mathrm{He} /{ }^{4} \mathrm{He}=0.01 \sim 0.05 \mathrm{R} / \mathrm{Ra}\right.$ ) 和地幔氦 $\left({ }^{3} \mathrm{He} /{ }^{4} \mathrm{He}=6 \sim 9 \mathrm{R} / \mathrm{Ra}\right)$ 的 ${ }^{3} \mathrm{He} /{ }^{4} \mathrm{He}$ 比值存在高 达近 1000 倍的差异, 即使地壳流体中有少量幔源氦 的加入, 用氦同位素也易于判别出来 ${ }^{[59]}$, 因此稀有气 体同位素被作为幔源组分最灵敏的示踪剂, 在研究 成矿流体来源及其演化发挥了重要作用. 铅同位素 由于其质量大, 同位素间的相对质量差较小, 外界条 件的变化对其组成的影响很小, 故铅同位素组成具 有明显的“指纹特征”[65 68]. 由于现有不同的地质体 的物质来源, 成因机制, 形成环境及形成时间不一, 因而就各自具有不同的铅同位素标记特征，故铅同 位素可作为物质来源的可靠示踪计 [65]. 前人过去对 华北地块南缘钼矿床成矿流体来源和演化的研究, 主要侧重于 $\mathrm{H}, \mathrm{O}, \mathrm{S}$ 和C等同位素方法 $[11,22,24,26]$, 尚末 进行过流体包裹体稀有气体同位素研究. 本文以华 北地块南缘的金堆城、东沟、石家湾和三道庄等钼矿 床为例, 首次报道了东秦岭钼矿带几个典型钼矿床 成矿流体的氦和氩同位素组成, 并结合矿床的铅同 位素分析结果, 研究了成矿流体来源、演化及其与秦 岭造山带中-新生代陆内碰撞造山过程的成因联系, 探讨了成岩成矿的区域地球动力学背景, 为全面深 入认识秦岭造山带后造山期陆内造山作用过程提供 了新的证据.

\section{1 区域地质和矿床地质特征}

东秦岭钼矿带位于秦岭造山带的华北地块南缘 构造单元内, 天水-宝鸡-潼关-宜阳-鲁山-线 $\left(F_{1}\right)$ 以南 和洛南-㴒川断裂 $\left(F_{2}\right)$ 以北区间.东秦岭钼矿带主要表 现为受造山期后构造-岩浆活动带的控制, 在空间上 矿床多沿构造-岩浆带展布, 已知主要岩体约 100 个 展布方向与该深断裂大体一致, 走向 EW-NWW, 控 矿断裂以 $\mathrm{NW}$ 向的张性断裂系统为主(图 1). 东秦岭 含钼斑岩(面积小于 $1 \mathrm{~km}^{2}$ )主要为钾长花岗斑岩、二 长花岗斑岩和石英花岗斑岩. 岩体规模小, 平面形态 为等轴状或长条形, 剖面上为筒状或漏斗状. 岩体具 典型的斑状结构. 含钼斑岩的侵位与定位主要受断 裂控制, 岩体直接产于断裂带中, 所有小斑岩体均沿 断裂带成群成带分布.含钼斑岩属钙碱性岩系, 具高 硅、富碱、贫镁、低钙和钾大于钠等显著特征. 钼矿
化发育在岩体内部、接触带及围岩中, 矿石为细脉浸 染状. 主要金属矿物为辉钼矿和黄铁矿, 伴生白铇矿 及黄铜矿、磁铁矿等. 矿体的热液蚀变具渗透性面式 蚀变, 且常以岩体与围岩的接触带为中心, 分别向岩 体和围岩对称分布. 东秦岭钼矿床分为斑岩型、斑岩矽卡岩型和热液碳酸盐脉型 3 类, 其中斑岩型矿床以 金堆城、东沟和石家湾等钼矿床为典型代表, 南泥湖三道庄、上房沟矿床则是斑岩-矽卡岩型矿床的典型 代表, 热液碳酸盐脉型矿床出露较少, 以黄龙铺矿床 为典型代表.

金堆城钼矿床矿体以金堆城花岗斑岩为中心, 矿化与蚀变发育于斑岩体及其外接触带范围, 自斑 岩体向外呈现有规律的面型蚀变: 钾长石化-绢英岩 化-硅化-青磐岩化. 矿区出露地层为中元古界熊耳群 火山岩和上元古界官道口群高山河组石英砂岩、泥岩 和板岩. 辉钼矿呈细脉、网脉状分布于花岗斑岩与熊 耳群安山玢岩中. 矿石类型分为 3 种: 花岗斑岩型、 变安山岩型、板岩-石英岩型. 各蚀变带矿化均由不同 矿物组合的交错细脉所组成.

石家湾钼矿床产于石家湾花岗斑岩体与熊耳群 火山岩和高山河组石英砂岩的接触蚀变带中, 位于 老牛山岩基东侧突出部位. 斑岩体出露长度 $600 \mathrm{~m}$, 宽 30 130 m, 面积约 $0.06 \mathrm{~km}^{2}$, 是一沿北西向断裂侵 入到熊耳群火山岩和高山河组沉积岩地层中的不规 则状岩枝. 钼矿化特征与金堆城矿床类似.

东沟钼矿床赋存于东沟钾长花岗斑岩体与熊耳 群火山岩的接触带附近. 含矿花岗斑岩体地表呈 NE 向延伸, 长 $250 \mathrm{~m}$, 宽 $50 \mathrm{~m}$, 出露面积 $0.01 \mathrm{~km}^{2}$. 深部 岩体长 $1550 \mathrm{~m}$, 宽 $850 \mathrm{~m}$, 面积 $1.32 \mathrm{~km}^{2}$. 岩体向四 周外倾. 钼矿化面积约 $3.6 \mathrm{~km}^{2}$. 矿体平面上呈长方 形, 形态严格受花岗斑岩体顶面的形态制约. 辉钼矿 赋存于石英细脉或钾长石-石英细脉内及其两侧.

三道庄钼铇矿床产于远离接触带的夕卡岩中, 矿体呈层状、似层状赋存于夕卡岩和大理岩中, 与钼 矿化有关的岩浆岩主要有鱼库和马圈等钾长花岗斑 岩体. 矿石类型主要为夕卡岩型, 角岩型和花岗斑岩 型. 辉钼矿可见于各种类型的矿石中, 多呈细(网)脉 或薄膜状产出.

\section{2 分析测试方法与测定结果}

\section{1 黄铁矿流体包裹体氦和氩同位素}

东秦岭钼矿床流体包裹体研究表明 ${ }^{[18,22,24]}$, 其流 
体包裹体特征和类型与浆控高温热液成矿系统的流 体包裹体 ${ }^{[34]}$ 相似, 流体包裹体以气液包裹体为主, 常 可见 $\mathrm{CO}_{2}-\mathrm{H}_{2} \mathrm{O}$ 包裹体(包括富 $\mathrm{CO}_{2}$ 包裹体). 流体包裹 体主要为原生包裹体, 次生包裹体较少. 流体包裹体 形态主要呈椭圆型, 次为不规则型, 包裹体大小通常 为 $5 \mu \mathrm{m} \times 5 \mu \mathrm{m}$ 到 $10 \mu \mathrm{m} \times 10 \mu \mathrm{m}$, 大者可达 $25 \mu \mathrm{m} \times$ $25 \mu \mathrm{m}$; 气液比一般介于 $10 \%$ 30\%; 均一温度介于 $150^{\circ} \mathrm{C} 350^{\circ} \mathrm{C}$ 间, 流体含盐度变化于 $10 \mathrm{wt} \% \sim 35 \mathrm{wt} \%$ (wt\%, 质量百分, 下同) $\mathrm{NaCl}$ 之间. 东秦岭钼矿床流 体包裹体综合对比研究显示, 初始成矿流体具有高 温、高盐度、高氧化性、富 $\mathrm{CO}_{2}$ 的特征, 随成矿作用 进行, 流体成矿系统的温度、盐度、氧化性、 $\mathrm{CO}_{2}$ 含 量等逐步降低, 至晚阶段成矿流体具有低温、低盐 度、贫 $\mathrm{CO}_{2}$ 的特征, 但氧化性又有所增强, 显示大气 降水热液的性质 ${ }^{[34]}$.

本研究所用于流体包裹体氦和氩同位素测定的 样品均为热液成矿阶段石英-硫化物细(网)脉中与辉 钼矿共生的热液成因黄铁矿. 黄铁矿流体包裹体氦 和氩同位素组成测定在中国科学院矿床地球化学国 家重点实验室完成. 流体包裹体的氦-氩同位素组成 由全金属静态高真空稀有气体质谱仪(GV5400)测定, 仪器的主要技术参数: 氦测定灵敏度为 $3.9725 \times 10^{-4}$ $\mathrm{A} /$ Torr $\left(1\right.$ Torr $=1.33 \times 10^{2} \mathrm{~Pa}$ ); 氩为 $1.1018 \times 10^{-3} \mathrm{~A} /$ Torr; 法拉第杯的分辨率为 228.1 , 电子倍增器的分辨率为 为 682.3. 实验处理方法步骤可概括为: (1) 将挑选好的 单矿物在超声波丙酮溶液中洗净烘干; (2) 称取 500 1000 mg 矿物装入螺旋式压碎装置; (3) 将样品 装入的烘烤螺旋式加热装置中烘烤, 温度保持在 120 $150^{\circ} \mathrm{C}$ 之间, 以除掉矿物和装置吸附的大气成分, 并把系统抽成高真空状态; (4) 在高真空条件下 $\left(10^{-8}\right.$ Torr)压碎样品, 使流体包裹体中的气体释放, 进入气体
净化系统; (5) 气体被纯化后, 使用液氮将重稀有气体 冷冻在活性炭冷阱中, 与氦分离; (6) 将纯化分离后的 稀有气体送入主机中进行同位素分析. 氦和氩同位素 的分析误差一般均小于 $10 \%$. 华北地块南缘钼矿床矿 物流体包裹体的氦、氩同位素组成分析结果见表 1. 华 北地块南缘钼矿床黄铁矿流体包裹体的 ${ }^{3} \mathrm{He} /{ }^{4} \mathrm{He}$ 比值为 1.38 3.64 Rc/Ra, ${ }^{40} \mathrm{Ar} /{ }^{36} \mathrm{Ar}$ 比值为 295.68 346.39.

\section{2 矿床铅同位素组成}

为了探讨华北地块南缘钼矿床氦-氩同位素与铅 同位素的耦合关系, 我们收集了华北地块南缘钼矿 带中有关矿床和区域地层岩石的铅同位素数据, 并 选择该带具有代表性的金堆城钼矿床补充进行了铅 同位素分析，华北地块南缘钼矿带矿床矿石硫化物、 地层岩石和花岗斑岩的铅同位素组成结果见表 2. 铅 同位素分析在西北大学大陆动力学国家重点实验室 完成，采用 AG1-X8(200 400 mesh)离子交换树脂进 行分离, 同位素测试在该实验室的多接收电感耦合 等离子体质谱仪(MC-ICPMS, Nu Plasma HR, Nu Instruments, Wrexham, UK) 上采用静态模式 (Static mode)进行; Pb 同位素的比值采用外部加入 NBS 997 $\mathrm{Tl}$ 至分离后的样品中, 并利用 ${ }^{205} \mathrm{Tl} /{ }^{203} \mathrm{Tl}=2.3872$ 来校 正仪器的质量分馏, 同时用 NBS 981 进行外部校正. 测量期间 NBS98 标准给出 ${ }^{206} \mathrm{~Pb} /{ }^{204} \mathrm{~Pb}=16.937 \pm 1,{ }^{207} \mathrm{~Pb} /$ ${ }^{204} \mathrm{~Pb}=15.491 \pm 1,{ }^{208} \mathrm{~Pb} /{ }^{204} \mathrm{~Pb}=36.696 \pm 1$; BCR-2 标准给出 ${ }^{206} \mathrm{~Pb} /{ }^{204} \mathrm{~Pb}=18.742 \pm 1,{ }^{207} \mathrm{~Pb} /{ }^{204} \mathrm{~Pb}=15.620 \pm 1,{ }^{208} \mathrm{~Pb} /$ ${ }^{204} \mathrm{~Pb}=38.705 \pm 1$; 测量的 $\mathrm{Pb}$ 空白为 $0.1 \sim 0.3 \mathrm{ng}$.

\section{3 结果讨论}

\section{1 流体包裹体中存在地幔氦}

大量研究表明, 黄铁矿是研究成矿流体稀有气体同

表 1 华北地块南缘钼矿床黄铁矿流体包裹体的氦、氩同位素组成分析结果 ${ }^{a)}$

\begin{tabular}{lccccccccccc}
\hline 样品编号 & 矿床 & $R \mathrm{c} / \times 10^{-6}$ & $\mathrm{Rc} / \mathrm{Ra}$ & ${ }^{4} \mathrm{He}$ & ${ }^{3} \mathrm{He}$ & ${ }^{38} \mathrm{Ar} /{ }^{36} \mathrm{Ar}$ & ${ }^{40} \mathrm{Ar} \beta^{36} \mathrm{Ar}$ & ${ }^{40} \mathrm{Ar}$ & ${ }^{36} \mathrm{Ar}$ & ${ }^{40} \mathrm{Ar} /{ }^{4} \mathrm{He}$ & $\mathrm{F}^{4} \mathrm{He}$ \\
\hline $\mathrm{HN} 09$ & 东沟 & $(3.38 \pm 0.11)$ & $2.42 \pm 0.08$ & $5.98 \times 10^{-8}$ & $1.91 \times 10^{-13}$ & $0.197 \pm 0.003$ & $296.93 \pm 2.14$ & $8.52 \times 10^{-7}$ & $2.89 \times 10^{-9}$ & 0.068 & 125.03 \\
$\mathrm{HN} 10$ & 东沟 & $(5.10 \pm 0.02)$ & $3.64 \pm 0.02$ & $1.82 \times 10^{-6}$ & $8.53 \times 10^{-12}$ & $0.186 \pm 0.002$ & $346.39 \pm 0.42$ & $1.89 \times 10^{-6}$ & $5.48 \times 10^{-9}$ & 0.153 & 2006.75 \\
$\mathrm{HN34}$ & 三道庄 & $(1.94 \pm 0.05)$ & $1.38 \pm 0.03$ & $1.98 \times 10^{-7}$ & $3.74 \times 10^{-13}$ & $0.189 \pm 0.003$ & $301.64 \pm 1.12$ & $1.17 \times 10^{-6}$ & $3.90 \times 10^{-9}$ & 0.120 & 306.76 \\
$\mathrm{JD} 21$ & 金堆城 & $(2.56 \pm 0.05)$ & $1.83 \pm 0.04$ & $1.77 \times 10^{-7}$ & $4.37 \times 10^{-13}$ & $0.188 \pm 0.002$ & $295.68 \pm 0.86$ & $1.13 \times 10^{-6}$ & $3.85 \times 10^{-9}$ & 0.004 & 277.79 \\
$\mathrm{JD} 23-1$ & 金堆城 & $(4.77 \pm 0.03)$ & $3.41 \pm 0.02$ & $5.77 \times 10^{-7}$ & $2.60 \times 10^{-12}$ & $0.184 \pm 0.002$ & $316.04 \pm 0.47$ & $1.72 \times 10^{-6}$ & $5.44 \times 10^{-9}$ & 0.194 & 640.88 \\
$\mathrm{HL02-1}$ & 石家湾 & $(2.93 \pm 0.04)$ & $2.09 \pm 0.03$ & $2.20 \times 10^{-7}$ & $6.19 \times 10^{-13}$ & $0.188 \pm 0.003$ & $299.12 \pm 2.33$ & $1.44 \times 10^{-6}$ & $4.87 \times 10^{-9}$ & 0.079 & 272.96 \\
$\mathrm{HL02-3}$ & 石家湾 & $(1.93 \pm 0.03)$ & $1.38 \pm 0.02$ & $3.41 \times 10^{-7}$ & $6.31 \times 10^{-13}$ & $0.190 \pm 0.001$ & $298.96 \pm 1.20$ & $1.70 \times 10^{-6}$ & $5.69 \times 10^{-9}$ & 0.058 & 362.11 \\
\hline
\end{tabular}

a) $R_{\mathrm{c}}$ 为样品的 ${ }^{3} \mathrm{He} /{ }^{4} \mathrm{He}$ 比值, $R \mathrm{a}$ 为空气的 ${ }^{3} \mathrm{He} /{ }^{4} \mathrm{He}$ 比值 (取 $\left.1.40 \times 10^{-6}\right) ;{ }^{40} \mathrm{Ar}^{*}$ 表示扣除空气 ${ }^{40} \mathrm{Ar}$ 后的过剩氩, ${ }^{40} \mathrm{Ar} *=\left({ }^{40} \mathrm{Ar}\right)$ 样品 $-295.5 \times\left({ }^{36} \mathrm{Ar}\right)$ 样品; 分析测试者: 蒋国豪; HN09, HN10 为东沟斑岩型钼矿床安山岩型矿石内石英-硫化物脉中的黄铁矿; HN34 为三道庄夕卡岩型钼矿床夕 卡岩型矿石内硫化物-石英脉中黄铁矿; JD21, JD23-1 为金堆城斑岩型钼矿床花岗斑岩型矿石内黄铁矿-辉钼矿-石英脉中黄铁矿; HL02-3, HL02-1 为石家湾斑岩型钼矿床安山岩型矿石内硫化物-石英脉中的黄铁矿 
表 2 华北地块南缘钼矿床及区域地层岩石铅同位素组成

\begin{tabular}{|c|c|c|c|c|c|}
\hline 样品编号 & 样品描述 & ${ }^{206} \mathrm{~Pb} /{ }^{204} \mathrm{~Pb}$ & ${ }^{207} \mathrm{~Pb} /{ }^{204} \mathrm{~Pb}$ & ${ }^{208} \mathrm{~Pb} /{ }^{204} \mathrm{~Pb}$ & 资料来源 \\
\hline JD01 & 金堆城花岗斑岩中钾长石 & 17.872 & 15.508 & 38.082 & 本文 \\
\hline JD02 & 金堆城花岗斑岩中钾长石 & 18.251 & 15.528 & 38.115 & 本文 \\
\hline JD07 & 金堆城斑岩型矿石中黄铁矿 & 17.477 & 15.485 & 37.983 & 本文 \\
\hline JD23 & 金堆城钼矿床斑岩矿石中辉钼矿 & 17.589 & 15.490 & 38.198 & 本文 \\
\hline M0603 & 金堆城钼矿床熊耳群安山岩 & 17.707 & 15.495 & 38.001 & 本文 \\
\hline M0605 & 金堆城钼矿床熊耳群安山岩 & 17.005 & 15.427 & 37.710 & 本文 \\
\hline JD22 & 金堆城钼矿床熊耳群安山岩 & 16.982 & 15.427 & 37.594 & 本文 \\
\hline QYYTAVER1 & 区域矿化斑岩平均值 & 17.403 & 15.382 & 37.673 & 文献[12] \\
\hline 21 & 金堆城钼矿床含矿花岗斑岩 & 18.129 & 15.511 & 38.049 & 文献[9] \\
\hline 18 & 金堆城钼矿床黄铁矿-薥石-钾长石-石英脉中方铅矿 & 17.284 & 15.417 & 37.724 & 文献[9] \\
\hline 19 & 金堆城钼矿床黄铁矿-薥石-钾长石-石英脉中钾长石 & 17.536 & 15.438 & 37.680 & 文献[9] \\
\hline $\mathrm{DF}-2$ & 南泥湖-三道庄矿床钨钼矿石中方铅矿 & 17.450 & 15.540 & 39.010 & 文献[9] \\
\hline $\mathrm{J}-5$ & 南泥湖-三道庄矿床黑云母花岗闪长岩中钾长石 & 17.089 & 15.569 & 38.509 & 文献[9] \\
\hline $\mathrm{J}-4$ & 南泥湖-三道庄矿床玟状花岗岩中钾长石 & 17.894 & 15.482 & 38.193 & 文献[9] \\
\hline XIR01 & 区域熊耳群巨斑安山岩 ～～～～～ & 16.907 & 15.421 & 36.346 & 文献[12] \\
\hline XIR02 & 区域熊耳群安山岩 & 16.647 & 15.300 & 36.876 & 文献[12] \\
\hline XIR03 & 区域熊耳群杏仁安山岩 & 16.439 & 15.271 & 36.489 & 文献[12] \\
\hline XIR04 & 区域熊耳群闪长玢岩 & 16.451 & 15.358 & 36.887 & 文献[12] \\
\hline XIR05 & 区域熊耳群闪长玢岩 & 17.123 & 15.383 & 37.310 & 文献[66] \\
\hline XIR06 & 区域熊耳群高钾玄武安山岩 & 16.303 & 15.294 & 36.672 & 文献[66] \\
\hline XIR07 & 区域熊耳群玄粗岩 & 16.125 & 15.349 & 36.443 & 文献[66] \\
\hline XIR08 & 区域熊耳群高钾安山岩 & 16.258 & 15.275 & 37.267 & 文献[66] \\
\hline TH01 & 区域太华群斜长角闪岩 & 17.332 & 15.620 & 37.973 & 文献[29] \\
\hline ТH02 & 区域太华群黑云斜长片麻岩 & 17.373 & 15.420 & 40.447 & 文献[29] \\
\hline ТH03 & 区域太华群伟晶混合岩 & 16.892 & 15.203 & 37.242 & 文献[29] \\
\hline TH04 & 区域太华群钾长伟晶岩 & 16.368 & 15.192 & 35.902 & 文献[29] \\
\hline TH05 & 区域太华群角闪片麻岩 & 17.530 & 15.345 & 38.569 & 文献[31] \\
\hline TH06 & 区域太华群片麻岩 & 17.495 & 15.279 & 37.839 & 文献[31] \\
\hline TH07 & 区域太华群黑云母片麻岩 & 17.400 & 15.469 & 38.174 & 文献[31] \\
\hline TH08 & 区域太华群斜长角闪片麻岩 & 17.162 & 15.504 & 37.746 & 文献[31] \\
\hline ТH09 & 区域太华群混合岩 & 17.475 & 15.504 & 40.427 & 文献[30] \\
\hline TH010 & 区域太华群混合片麻岩 & 15.788 & 15.351 & 36.476 & 文献[30] \\
\hline TH011 & 区域太华群角闪片麻岩 & 19.428 & 15.667 & 41.260 & 文献[12] \\
\hline TH012 & 区域太华群黑云母片麻岩 & 17.353 & 14.492 & 42.558 & 文献[32] \\
\hline TH013 & 区域太华群斜长角闪岩 & 16.968 & 15.359 & 37.775 & 文献[32] \\
\hline TH014 & 区域太华群斜长角闪岩 & 17.609 & 15.547 & 37.654 & 文献[32] \\
\hline TH015 & 区域太华群黑云母片麻岩 & 15.406 & 15.188 & 37.526 & 文献[32] \\
\hline TH016 & 区域太华群角闪云斜片麻岩 & 16.511 & 15.512 & 36.266 & 文献[32] \\
\hline
\end{tabular}

位素组成的理想寄主矿物, 黄铁矿发生漏气程度远远小 于其他矿物 ${ }^{[39,46 ~ 50,59]}$, 流体包裹体被捕获后, 寄主矿物 黄铁矿晶格中由铀、针衰变所产生的放射成因 ${ }^{4} \mathrm{He}$ 难以 大量扩散进入流体包裹体, 包裹体溶液中因铀、针含量 很低, 由其衰变而产生的 ${ }^{4} \mathrm{He}$ 的量很少 ${ }^{[46 \sim 50,59]}$. 压碎寄主 矿物释放包裹体溶液的过程亦基本不致于使寄主矿物中 的 ${ }^{4} \mathrm{He}$ 释放出来. 黄铁矿中钾的含量很低, 因此其中 钾的衰变也不可能生成较可观的 ${ }^{40} \mathrm{Ar}^{[46,47,49,50]}$. 本研 究测试用的黄铁矿均具有完好晶形, 未见后期改造
的痕迹, 其中的流体包裹体当以原生包裹体为主, 这 与前述共生矿物石英中的流体包裹体基本上均为原 生包裹体的事实相一致. 因此, 分析样品中的矿后流 体(以次生包裹体形式存在) 不可能对样品的 $\mathrm{He}$ 和 $\mathrm{Ar}$ 同位素分析结果产生明显影响, 其流体包裹体中的 氦在流体包裹体被圈闭后不可能有明显丢失, 故其 流体包裹体中因He和Ar扩散丢失而引起的同位素分 馏及后生叠加的 $\mathrm{He}$ 和 Ar均可忽略不计 ${ }^{[46 ~ 50]}$. 氦在 大气中的含量极低, 不足以对地壳流体中氦的丰度 
和同位素组成产生明显影响, 而本研究所用的黄铁 矿样品均为采自地下坑道和采场未经长时间暴露于 空气中的新鲜样品, 故可排除样品中存在宇宙成因 ${ }^{3} \mathrm{He}$ 的可能性. 至于在黄铁矿流体包裹体分析测试过 程中, 大气对流体中氦的浓度的影响程度, 则可以根 据参数 $\mathrm{F}^{4} \mathrm{He}$ 来判断 ${ }^{[42]} . \mathrm{F}^{4} \mathrm{He}$ 为样品中 ${ }^{4} \mathrm{He} /{ }^{36} \mathrm{Ar}$ 与大气 ${ }^{4} \mathrm{He} /{ }^{36} \mathrm{Ar}$ 的比值 (大气的 ${ }^{4} \mathrm{He} /{ }^{36} \mathrm{Ar}=0.1655$ ). 假如样品 中含有大气氦, 则 $\mathrm{F}^{4} \mathrm{He}=1$. 华北地块南缘钼矿床黄 铁矿流体包裹体中 $F^{4} \mathrm{He}$ 远远大于l(表 1), 最高可达 2000 多倍, 故可以排除大气对流体包裹体中氦的混 染作用. 由以上分析可见, 华北地块南缘钼矿床流体 包裹体 ${ }^{3} \mathrm{He} /{ }^{4} \mathrm{He}$ 和 ${ }^{36} \mathrm{Ar} /{ }^{40} \mathrm{Ar}$ 比值不会因上述后生过程 的影响而发生变化, 即黄铁矿中流体包裹体的 $\mathrm{He}-\mathrm{Ar}$ 同位素测定值基本代表原生流体包裹体或成矿流体 的的氦和氩同位素组成初始值.

已有研究显示 ${ }^{[39,59]}$ ，地质体中不同来源地质流 体的 ${ }^{3} \mathrm{He} /{ }^{4} \mathrm{He}$ 和 ${ }^{40} \mathrm{~A} \mathrm{r} /{ }^{36} \mathrm{Ar}$ 有明显的区别, 如：(1) 大气 饱和水(ASW), 主要包括大气降水和海水等, 其特征 性 ${ }^{3} \mathrm{He} /{ }^{4} \mathrm{He}$ 和 ${ }^{40} \mathrm{Ar} /{ }^{36} \mathrm{Ar}$ 同位素组成分别为 $1 R \mathrm{a}$ 和 295.5; (2) 深源地幔流体, 其特征性 ${ }^{3} \mathrm{He} /{ }^{4} \mathrm{He}$ 和 ${ }^{40} \mathrm{Ar} /{ }^{36} \mathrm{Ar}$ 值 分别应为 6 9 $R \mathrm{a}$ 和 $>40000$; (3) 地壳流体, 主要指与 地壳岩石发生过相互作用的饱和空气大气水, 其特 征性 ${ }^{3} \mathrm{He} /{ }^{4} \mathrm{He}$ 和 ${ }^{40} \mathrm{Ar} /{ }^{36} \mathrm{Ar}$ 组成分别应为 $0.01 \sim 0.05 \mathrm{Ra}$ 和 $>295.5$. 大陆地壳氦为放射性成因, 是铀、针放射 性衰变及其中子反应(主要与 Li)的产物, 其 ${ }^{3} \mathrm{He} /{ }^{4} \mathrm{He}$ 值取决于地壳中铀、针和锂的含量, 但其特征值约为 0.01 0.05 Ra ${ }^{[46 ~ 50,59]}$. 华北地块南缘钼矿床矿区的铀、 针和锂的背景值与地壳平均值接近 ${ }^{[4]}$, 指示该区地壳 的 ${ }^{3} \mathrm{He} /{ }^{4} \mathrm{He}$ 值应于地壳特征值 $(0.01 \sim 0.05 \mathrm{Ra})$ 相似. 由 表 1 测定结果可见, 华北地块南缘钼矿床黄铁矿流体 包裹体的 ${ }^{3} \mathrm{He} /{ }^{4} \mathrm{He}$ 比值为 $1.38 \sim 3.64 \mathrm{Ra},{ }^{40} \mathrm{Ar} /{ }^{36} \mathrm{Ar}$ 比值 为 $295.68 \sim 346.39$, 比较接近或高于大气氩的同位素 组成 $\left({ }^{40} \mathrm{Ar} /{ }^{36} \mathrm{Ar}=295.5\right){ }^{[59]}$, 但 ${ }^{3} \mathrm{He} /{ }^{4} \mathrm{He}$ 比值(表 1)远高 于地壳特征值 $(0.01 \sim 0.05 \mathrm{Ra})$, 是地壳比值的 20 300 倍, 并在一定的程度上与地幔特征值趋近, 但又低于 地幔值, 说明成矿流体中存在大量地幔氦, 并有部分 放射性地壳 ${ }^{4} \mathrm{He}$ 的加入. 在 ${ }^{3} \mathrm{He}-{ }^{4} \mathrm{He}$ 同位素演化图解 (图 2)上, 成矿流体的氦同位素组成的投点均位于地 壳与地幔组成的过渡带, 并偏于地幔组成一侧, 其 ${ }^{3} \mathrm{He} /{ }^{4} \mathrm{He}$ 比值在 $10^{-5} \sim 10^{-6}$ 之间, 显示了地幔与地壳混 合组成的特点. 将黄铁矿流体包裹体的He和Ar同位 素组成投人 ${ }^{3} \mathrm{He} /{ }^{4} \mathrm{He}-{ }^{40} \mathrm{Ar} /{ }^{36} \mathrm{Ar}$ 图(图 3), 可以看出 $\mathrm{He}$ 和
$\operatorname{Ar}$ 同位素组成具有一定的正相关关系，主要点集中在 地幔流体和地壳流体之间, 显示成矿流体可能是一个 地幔流体和地壳流体混合的结果.

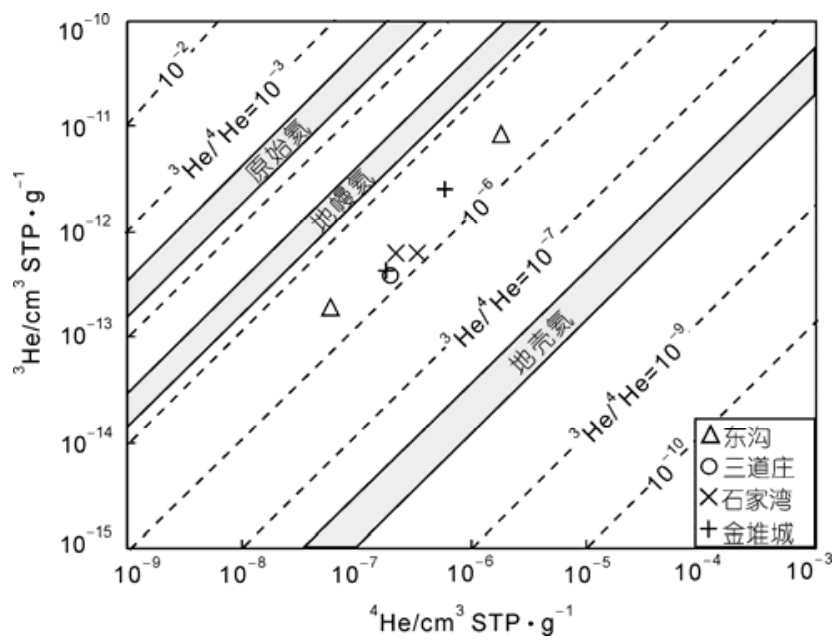

图 2 华北地块南缘钼矿床黄铁矿流体包裹体 ${ }^{3} \mathrm{He}-{ }^{4} \mathrm{He}$ 图 解(底图据文献[43])

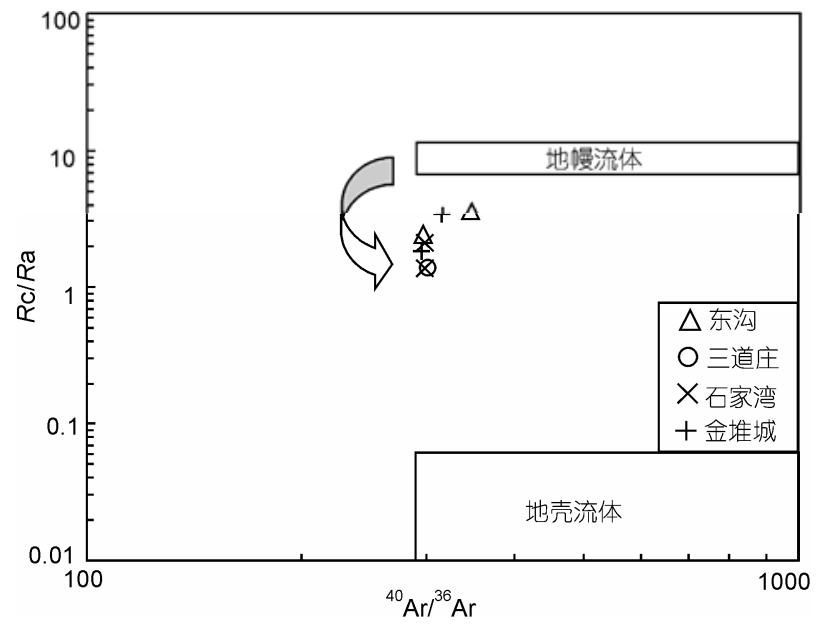

图 3 华北地块南缘钼矿床黄铁矿流体包裹体 $\mathrm{Rc} / \mathrm{Ra}^{\mathrm{40}}{ }^{\mathrm{A}} \mathrm{Ar} /{ }^{36} \mathrm{Ar}$ 图解

地幔流体的 ${ }^{40} \mathrm{Ar}^{*} /{ }^{4} \mathrm{He}$ 比值为 $0.33 \sim 0.56^{[40]}$, 地壳 流体的 ${ }^{40} \mathrm{Ar}^{*} /{ }^{4} \mathrm{He}$ 的平均值为 $0.156^{[48,59]}$. 从图 4 可以 看出, 华北地块南缘钼矿床成矿流体的 ${ }^{40} \mathrm{Ar}^{*} /{ }^{4} \mathrm{He}$ 比 值为 $0.004 ~ 0.194$ (平均值为 0.097 ), 也位于地幔流体 与地壳流体之间, 但其地壳流体端元的 ${ }^{40} \mathrm{Ar}^{*} /{ }^{4} \mathrm{He}$ 大 大低于正常地壳流体的 ${ }^{40} \mathrm{Ar}^{*} /{ }^{4} \mathrm{He}$ 比值(0.156). 已有 研究表明, 现代大气降水 ${ }^{40} \mathrm{Ar}^{*} /{ }^{4} \mathrm{He}$ 值的降低, 是地下 水从流经岩石中优先(相对于 ${ }^{40} \mathrm{Ar}$ ) 获取 ${ }^{4} \mathrm{He}$ 的结果 [46,47,49,50,62]. 地下水在地壳中获取放射性成因 ${ }^{4} \mathrm{He}$ 和 ${ }^{40} \mathrm{Ar}$, 与氦和氩的封闭温度有关, 对于大多数矿物 
而言, 氦的封闭温度很低 $\left(200^{\circ} \mathrm{C}\right)$, 而氩的封闭则高 得多 $\left(>200^{\circ} \mathrm{C}\right)^{[37]}$. 华北地块南缘钼矿成矿流体中地壳 流体端元对地壳岩石中氦的优先富集 $\left({ }^{40} \mathrm{Ar}^{*} /{ }^{4} \mathrm{He} 大 大\right.$ 低于正常地壳流体的 ${ }^{40} \mathrm{Ar}^{*} /{ }^{4} \mathrm{He}$ 比值), 说明这一流体 端元是一种低温 $\left(<200^{\circ} \mathrm{C}\right)$ 地下水.

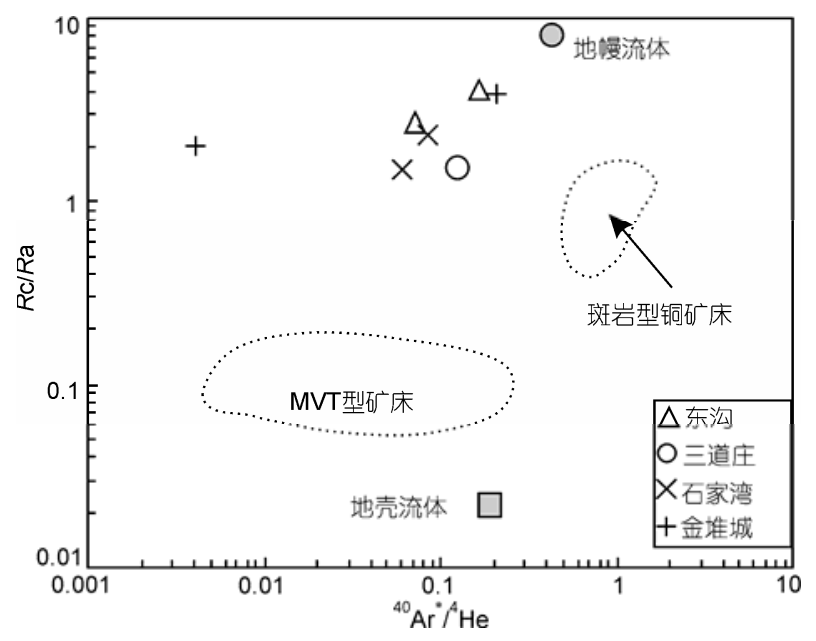

图 4 华北地块南缘钼矿床黄铁矿流体包裹体 $R \mathrm{c} / \mathbf{R a}-$

${ }^{40} \mathrm{Ar}^{*} /{ }^{4} \mathrm{He}$ 图解(底图据文献[36])

华北地块南缘钼矿床属与含钼斑岩体密切时空 联系的斑岩型或矽卡岩型矿床, 由此推断成矿流体 中的“地幔”端元, 应是含钼斑岩岩浆同源的深源流 体, 当深源流体上升与大气降水发生混合时, 则形成 含大气降水的中低温混合流体. 考虑到本区含钼斑 岩为壳-幔混合成因 ${ }^{[7,17,21]}$, 在成岩期间已混入部分地 壳物质, 因此其分异流体的 ${ }^{3} \mathrm{He} /{ }^{4} \mathrm{He}$ 值当比典型陆下 地幔值(6 7 Ra)低. 前文华北地块南缘钼矿床成矿流 体He和Ar的同位素组成特征支持, 成矿流体中除存 在与斑岩岩浆同源的深源流体端元外, 同时还存在大 气成因的低温地下水端元. 因此, 相对于地幔正常值, 华北地块南缘钼矿床成矿流体的 ${ }^{3} \mathrm{He} /{ }^{4} \mathrm{He}$ 值偏低, 最可 能原因是地壳大气降水氦对地幔氦稀释的结果. 如果 假设含钼斑岩中的氦约有 $70 \%$ 来自地幔, 其余 $30 \%$ 左 右为地壳成因, 那么这种岩浆分异深源流体的 ${ }^{3} \mathrm{He} /{ }^{4} \mathrm{He}$ 值就应在 $4 \mathrm{Ra}$ 左右. 若以 $4 \mathrm{Ra}$ 作为岩浆分异深源流体 的 ${ }^{3} \mathrm{He} /{ }^{4} \mathrm{He}$ 值, 根据二元混合模式, 成矿流体中与岩 浆同源的深源流体端元提供的氦, 应在成矿流体总 氦的 $29 \%$ 74\%之间, 其余氦则来自成矿流体的大气 成因地下水端元. 华北地块南缘钼矿床成矿流体氢 氧同位素研究也表明 ${ }^{[8,11,22,24]}$, 从成矿前阶段 $\rightarrow$ 成矿

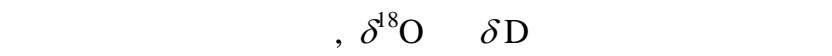

势, 指示成矿流体早期主要来自深部岩浆热液, 晚期 伴有雨水加入.

\section{2 成岩成矿物质中的铅属于深源铅}

东秦岭主要含钼斑岩体及矿石硫化物铅同位素 组成变化范围不大 $\left({ }^{206} \mathrm{~Pb} /{ }^{204} \mathrm{~Pb}=17.089 \sim 18.251\right.$, 平均 值 17.634; ${ }^{207} \mathrm{~Pb} /{ }^{204} \mathrm{~Pb}=15.382 ~ 15.569$, 平均值 15.486; ${ }^{208} \mathrm{~Pb} /{ }^{204} \mathrm{~Pb}=37.673 \sim 39.010$, 平均值 38.111), 而区域 地层岩石如熊耳群安山岩 $\left({ }^{206} \mathrm{~Pb} /{ }^{204} \mathrm{~Pb}=16.125 \sim 17.707\right.$, 平均值 $16.722 ;{ }^{207} \mathrm{~Pb} /{ }^{204} \mathrm{~Pb}=15.271 \sim 15.495$, 平均值 15.364; ${ }^{208} \mathrm{~Pb} /{ }^{204} \mathrm{~Pb}=36.346 \sim 38.001$, 平均值 37.054)和太 华群片麻岩 $\left({ }^{206} \mathrm{~Pb} /{ }^{204} \mathrm{~Pb}=15.406 ~ 19.428\right.$, 平均值 17.131; ${ }^{207} \mathrm{~Pb} /{ }^{204} \mathrm{~Pb}=14.492 \sim 15.667$, 平均值 $15.353 ;{ }^{208} \mathrm{~Pb} /{ }^{204} \mathrm{~Pb}=$ 35.902 42.558, 平均值 38.365)的铅同位素组成变化 较大, 且其同位素比值比矿石硫化物和花岗斑岩明 显普遍偏低(表 2). 如果考虑到地层全岩岩石中存在 因U和Th衰变而加入的放射性成因铅的加入, 则地层 岩石的初始铅的同位素比值相对矿石硫化物和花岗 斑岩会更低, 则可以认为矿石和斑岩中的铅不可能 主要来自地层岩石, 说明与斑岩体同源的成矿流体 在成矿过程中可能没有萃取周围地层岩石中的成矿 物质. 这也从另一个侧面证实成矿物质主要来自深 源. 在Zartman铅构造模式图解 ${ }^{[67]}$ 中(图 5), 花岗斑岩 和矿石铅同位素组成投点接近, 具有集中分布特点, 而与地层全岩岩石(太华群和熊耳群)差异较大, 且分 布趋势不同; 花岗斑岩及矿石主要落在地幔线和造 山带线或下地壳线之间, 多数靠近地幔线, 表明成矿 流体中铅等成矿物质主要来源于深部地幔, 而造山 带本身代表了壳幔混合来源, 进一步说明花岗斑岩 和矿石中具有相同的铅源, 主要属深源铅, 即为地幔 与下地壳的混合成因铅.

\section{3 成岩成矿的动力学背景}

本文对东秦岭钼矿带几个典型矿床的稀有气体 同位素研究证实东秦岭钼矿床成矿流体中主要存在与 壳幔混合成因斑岩体同源的高温深源流体和富含地壳 放射成因氦但具有空气氩同位素组成特征的低温大气 降水. 因此, 华北地块南缘钼矿床的形成可能与秦岭 造山带碰撞造山后的陆内造山和伸展过程相伴的壳幔 相互作用有关, 与钼矿化有关的斑岩可能属同熔型花 岗岩类, 而非简单的陆壳重熔型花岗岩类或 $S$ 型花岗 岩. 以下地质-地球化学事实支持华北地块南缘斑岩 体的侵入和钼矿化的形成发生于秦岭造山带中新生代 

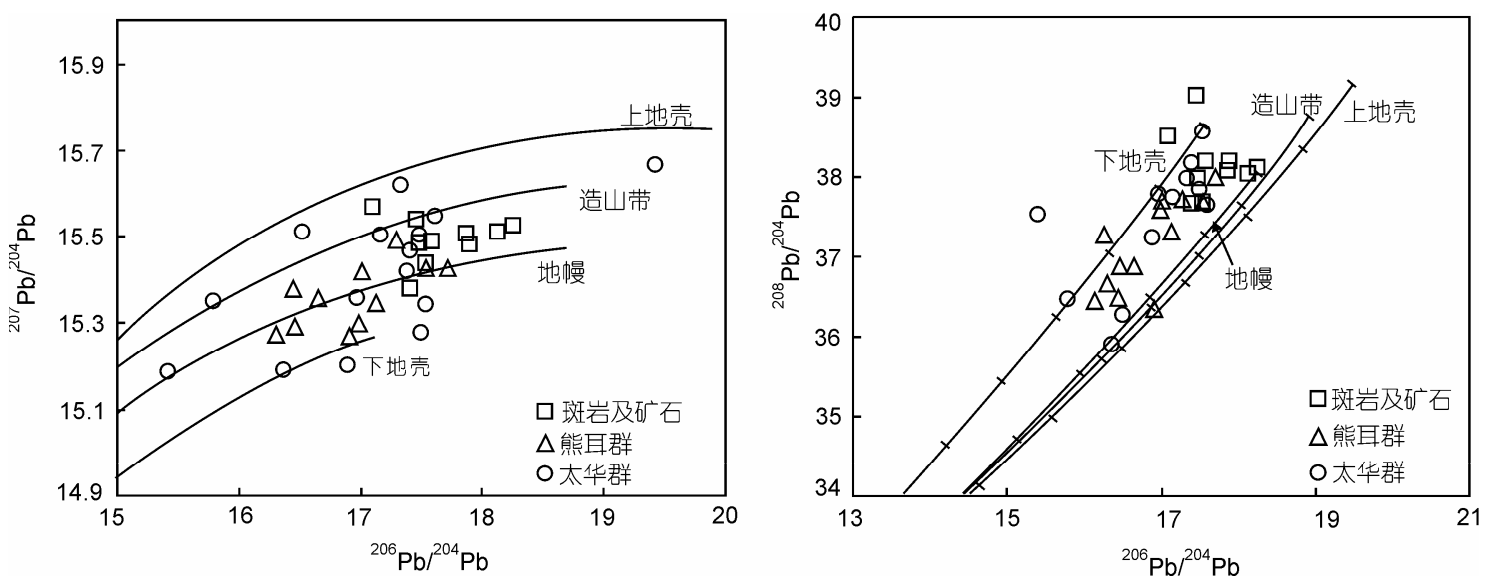

图 5 华北地块南缘金堆城钼矿床铅同位素构造环境图解(底图据文献[67])

陆内造山作用阶段, 与深部地幔动力学的最新调整到 上部地壳响应所关联的壳幔相互作用有关:

(1) 尽管目前国内外对花岗岩的氦同位素组成 研究还较少, 只有少量花岗岩的 ${ }^{3} \mathrm{He} /{ }^{4} \mathrm{He}$ 值, 但是与 $\mathrm{S}$ 型花岗岩和与之有关的热液矿床并没有发现幔源氦 的存在. 如Burnard等人 ${ }^{[38]}$ 对葡萄牙中部与 $S$ 型花岗岩 相伴的Panasqueira W-Cu(Ag)-Sn石英脉型矿床毒砂和 黑铇矿流体包裹体的He和 $\mathrm{Ar}$ 同位素研究发现，成矿流 体较高的 ${ }^{3} \mathrm{He} /{ }^{4} \mathrm{He}$ 和 ${ }^{40} \mathrm{Ar} /{ }^{36} \mathrm{Ar}$ 比值 $\left({ }^{3} \mathrm{He} /{ }^{4} \mathrm{He}=4.2 \sim 5.5\right.$ $\left.R a ;{ }^{40} \mathrm{Ar} /{ }^{36} \mathrm{Ar} \approx 295.5 \sim 950\right)$, 指示成矿流体存在深部 地幔流体端元, 但是同位素物质平衡计算表明这种 流体不可能来自 $\mathrm{S}$ 型花岗岩浆, 而是来自深部地幔流 体; 赵葵东等人 ${ }^{[64]}$ 对我国大厂锡-多金属矿床成矿流 体来源的He同位素研究表明, 与花岗岩有关的萤石 样品的 ${ }^{3} \mathrm{He} /{ }^{4} \mathrm{He}$ 值为 $0.7 \mathrm{Ra}$, 认为与笼箱盖花岗岩有 关流体的惰性气体可能是大气降水与地壳放射成因 $\mathrm{He}$ 的混合而成; 乌克兰一些 $\mathrm{S}$ 型花岗岩的 ${ }^{3} \mathrm{He} /{ }^{4} \mathrm{He}$ 值仅为 $(0.014 \sim 0.017) \times 10^{-6}$, 为典型的放射成因 $\mathrm{He}^{[43]}$; Stuart等人 ${ }^{[59,60]}$ 研究了英国Pennines北部和英国西南 部与 $S$ 型花岗岩有关的Pb-Zn矿化的硫化物和萤石中 的流体包裹体的 $\mathrm{He}$ 和 $\mathrm{Ar}$ 同位素组成, 没有找到任何 地幔流体混入的证据, 是典型的放射成因He; Stuart 等人 ${ }^{[59]}$ 对韩国Dae Hwa W-Mo矿床白铇矿流体包裹 体研究证实, 成矿流体存在地幔流体端元, 但与矿化 有关的花岗岩已被大量研究确定为 I 型花岗岩, 而 非 $S$ 型花岗岩. 华北地块南缘钼矿床 ${ }^{3} \mathrm{He} /{ }^{4} \mathrm{He}$ 比值虽 然低于典型地幔流体来源的郯庐断裂带旁侧的我国 湖南万古金矿 ${ }^{[57]}$, 但可以与前人曾研究过的中国马 厂箐铜矿床、哀牢山金矿床、胶东地区金矿床、大渡
河金矿床、韩国Dae Hwa W-Mo矿床和秘鲁Casapalca and Pasto Bueno Ag-Pb-Zn-Cu矿床 ${ }^{[39,47,48,56,58,59,63]}$ 相 对比, 已有研究已经证实这些矿床的成矿流体中存 在幔源氦, 其 $R / R$ a值在 $0.1 \sim 3.0$ 之间, 这充分说明地 幔流体同样参与了华北地块南缘钼矿床的成矿作用 过程. 考虑到华北地块南缘钼矿床成矿流体中存在 “地幔”端元流体的客观事实, 因此可以推测与华北 地块南缘钼矿床是有关的斑岩不可能是 S-型花岗岩 或地壳重熔型花岗岩, 而可能是具有深部地质背景 的的壳-幔混合成因花岗岩或同熔型花岗岩.

(2) 已有对地幔流体包裹体的微量元素研究表 明, Mo显著地富集于地幔流体中 ${ }^{[69]}$. 华北地块南缘 与钼矿化有关的花岗斑岩富Mo, 如前人对该区 27 个 岩体 667 件样品Mo丰度统计获得平均值高达 59.02x $10^{-6}$; 而地层岩石如秦岭群、太华群、熊耳群、奕川 群、官道口群、淘湾群、宽坪群和二朗坪群的 $\mathrm{Mo}$ 丰 度平均值分别仅为 $2.34 \times 10^{-6}, 1.05 \times 10^{-6}, 0.37 \times 10^{-6}$, $0.3 \times 10^{-6} \sim 0.9 \times 10^{-6}, 0.26 \times 10^{-6} \sim 0.55 \times 10^{-6}, 0.52 \times 10^{-6}$, $0.98 \times 10^{-6}$ 和 $0.97 \times 10^{-6[21]}$, 表明东秦岭从基底到盖层 各时代地层的Mo含量都很低, 均低于相应的地壳丰 度值, 暗示斑岩体在成岩矿过程中可能没有萃取周 围地层的成矿物质. 前文矿床铅同位素示踪结果已 证实, 花岗斑岩和矿石具有相同的铅源, 主要为地幔 与下地壳的混合成因铅, 地层全岩(太华群和熊耳群) 岩石铅同位素与花岗斑岩和矿石差异较大, 且分布 趋势不同也进一步说明成矿物质主要来自与花岗斑 岩同源的深源地幔流体，而非地层岩石.

（3）秦岭地表地质和地球化学研究及多种地球 物理探测结果表明，秦岭造山带具流变学分层的“立 
交桥”式三维结构, 秦岭现今岩石圈结构从上部东西 走向古构造为主经中部水平流变过渡层到深部最新 南北向地幔流变结构, 上下成近于直交或斜交关系, 呈现为非耦合的圈层关系, 构成具流变学分层的“立 交桥”式三维结构几何学框架 ${ }^{[2 \sim 4]}$. 华北地块南缘斑 岩体的锆石 $\mathrm{U}-\mathrm{Pb}$ 和辉钼矿 Re-Os年龄基本一致于 140 $\mathrm{Ma}$ 左右 ${ }^{[7,10,16,19]}$ ，显示成岩成矿发生于侏罗纪-白严 纪的同一成岩成矿系统中, 与发生于中国东部构造 体制大转换晚期的伸展地球动力学事件相吻 合 ${ }^{[70]}$. 事实上, 这一时期也正是秦岭造山带构造体制发生 转换的关键时期. 秦岭前中生代长期受冈瓦纳、劳亚 和古特提斯等古板块构造的控制, 形成东西向为主 的主造山期构造; 中新生代以来位于太平洋板块、印 度板块和欧亚板块内西伯利亚地块 3 个构造动力学 系统的汇交复合部位, 东部更多受太平洋板块的影 响, 使之正处于前后两期动力学系统转换时期和过 程之中 ${ }^{[1 \sim 4]}$, 原秦岭造山带中华北板块、扬子板块及 秦岭微板块三板块的俯冲造山形成的岩石圈根, 在 中新生代新的地幔动力学系统中, 东部地幔流动型 式与方向发生向太平洋的近 SN向物理场结构与状态 的调整转换 ${ }^{[4,71]}$, 引起秦岭岩石圈地幔拆沉作用 ${ }^{[15]}$, 岩石圈减薄, 软流圈急剧抬升, 幔源物质和热流流体 上涌, 必然发生强烈壳幔物质交换, 中下地壳加热, 加厚的下地壳物质发生熔融形成花岗质岩浆, 沿构 造薄弱带上升到浅层次侵位只能形成与同熔型而非 $\mathrm{S}$ 型花岗岩有关的斑岩型或矽卡岩型钼矿床.

(4) 斑岩的成因类型取决于诱发其形成的陆内 俯冲的深度, 如果俯冲深度超过莫霍面并诱发地幔 分熔而产生斑岩, 则斑岩只能是同熔型花岗岩类, 而 非 $S$ 型花岗岩. 已有研究表明, 华北地块南部向秦岭 的陆内俯冲, 是秦岭现今三维结构的基本组成部分, 具有统一的动力学背景 ${ }^{[2 \sim 4]}$. 东秦岭钼矿带成矿上主 要表现为受造山期后构造-岩浆活动带的控制, 在空 间上矿床多沿构造-岩浆带展布, 含钼斑岩和与之相 关的钼矿床分布范围限定在天水-宝鸡-潼关-渑池-宜 阳-线 $\left(\mathrm{F}_{1}\right)$ 以南和洛南-滦川断裂 $\left(\mathrm{F}_{2}\right)$ 以北区间内(图 1), 属于秦岭造山带的华北板块南缘构造单元. 已有研 究表明, 秦岭复合型造山带现今的北界是天水-宝鸡潼关-渑池-宜阳-鲁山-午阳-线(图 1, $\mathrm{F}_{1}$ ), 呈宽缓波状 弧形展布, 沿此线自西而东发育基本连续成带分布 的自南向北的逆冲推覆构造, 而成为现今秦岭造山 带与华北地块间的地质分界线 (秦岭北缘逆冲推覆
带). 该线以北属华北地块, 以南至洛南-㴒川断裂 $\left(\mathrm{F}_{2}\right)$ 以北区间, 虽然具有华北地块基底与盖层的结构和 组成(原曾属华北地块组成部分), 但现今从其构造变 形、变质、岩浆活动与成矿作用综合地质特征判别, 它是在秦岭晚古生代-中生代初期板块碰撞造山之后, 于中新生代陆内造山作用过程中, 加入秦岭造山活 动, 成为秦岭造山带现今的北缘组成部分 ${ }^{[2]}$. 东秦岭 DQL 和QB-1 等以反射地震为主的综合地球物理探测 $[2 \sim 4,33,72,73]$ 一致揭示秦岭造山带北缘沿 $F_{1}$ 一线出现华 北地块自北向南的巨型陆内俯冲带, 深入上地幔, 切 过现今的Moho面, 并与地表的自南向北的秦岭北缘 逆冲推覆构造相伴而生, 充分证明后者并非地壳上 部浅层表生重力滑动构造或地壳层次上发生的拆离、 滑脱, 推覆和堆叠构造等, 而是前者陆内深俯冲所导 生的上部地壳必然构造产物, 因而具有深刻的深部 动力学背景.

\section{4 结论}

(1) 本文对华北地块南缘东秦岭钼矿带几个典 型矿床的稀有气体同位素研究再次证实东秦岭钼矿 床成矿流体中主要存在深源地幔流体和大气降水. 与钼矿化有关的斑岩属与同熔型花岗岩类, 而非简 单的陆壳重熔型花岗岩类或 $S$ 型花岗岩. 华北地块南 缘钼矿床的形成可能与秦岭造山带碰撞造山后的陆 内造山和伸展过程相伴的壳幔相互作用有关, 华北 地块南部自北向南向秦岭的巨型陆内俯冲带, 俯冲 作用深达 Moho 面以下, 与之相伴在中上地壳发育了 自南向北的逆冲推覆构造带, 成为秦岭与华北地块 间中新生代重要陆内构造.

（2）秦岭中新生代陆内造山作用, 在深部复合的 地幔动力学背景下, 岩石圈地壳处于复杂的区域构 造应力场与应变场之中, 发生地壳水平缩短迭置和 垂向加积, 强烈深源与壳源岩浆活动和多种构造迭 加复合, 导致其从深部地幔动力学的最新调整到上 部地壳响应所发生的壳幔等圈层相互作用, 因此具 有深刻的深部和区域地球动力学背景.

(3) 华北地块南缘钼矿床的形成与华北地块南缘 的壳幔相互作用有关, 钼矿床的成矿流体系由不同性 质和组成的两个端元流体混合而成: 与壳幔混合成因 斑岩体同源的高温深源流体和富含地壳放射成因氦, 但具有空气氩同位素组成特征的低温大气降水. 
致谢评审专家及编委对本文提出了建设性的修改意见, 野外工作得到了河南省地调院及金堆城钼业公司的大力支持 和帮助, 作者在此深表感谢.

\section{参考文献}

1 Meng Q R, Zhang G W. Geologic framework and tectonic evolution of the Qinling orogen, Central China. Tectonophysics, 2000, 323: 183 - 196 [doi]

2 张国伟, 郭安林, 刘福田, 等. 秦岭造山带三维结构及其动力学分析. 中国科学 D 辑: 地球科学, 1996, 26(增刊): 1一6

3 张国伟, 孟庆任, 刘少峰, 等. 华北地块南部巨型陆内俯冲带与秦岭造山带岩石圈现今三维结构. 高校地质学报, 1997, 3: 129-143

4 张国伟, 张本仁, 袁学诚, 等. 秦岭造山带与大陆动力学. 北京: 科学出版社, 2001.1-729

5 李诺, 陈衍景, 张辉, 等. 东秦岭斑岩钼矿带的地质特征和成矿构造背景. 地学前缘, 2007, 14: 186-198

6 陈衍景, 李超, 张静, 等. 秦岭钼矿带斑岩体锶氧同位素特征与岩石成因机制和类型. 中国科学 D 辑: 地球科学, 2000, 30(增刊): 65-72

7 朱赖民，张国伟，郭波，等.东秦岭金堆城大型斑岩钼矿床 LA-ICP-MS 锆石 U-Pb 定年及成矿动力学背景. 地质学报，2008，82: $204-220$

8 黄典豪，董群英，甘志贤。中国钼矿床．宋叔和，主编。中国矿床．北京：地质出版社, 1989.482-512

9 黄典豪, 聂凤军, 王义昌, 等. 东秦岭地区钼矿床铅同位素组成特征及成矿物质来源初探. 矿床地质, 1984, 3: 20一 27

10 黄典豪, 吴澄宇, 杜安道, 等。东秦岭地区钼矿床的铼-锇同位素年龄及其意义. 矿床地质, 1994, 13: 221-230

11 罗铭玖, 张辅民，董群英，等。中国钼矿床。郑州：河南科学技术出版社, 1991. 118-128, 403-408

12 罗铭㺵. 河南金矿概论. 北京: 地震出版社, 1992. 1-312

13 许志琴, 卢一伦, 汤耀庆, 等. 东秦岭造山带的变形特征及构造演化. 地质学报, 1986, 60: 237-247

14 张本仁, 张宏飞, 赵志丹, 等. 东秦岭及邻区壳、幔地球化学分区和演化及其大地构造意. 中国科学 D 辑: 地球科学, 1996, 26: 201-208

15 高山，张本仁，金振民。秦岭-大别造山带下地壳拆沉作用. 中国科学 D 辑: 地球科学, 1999, 29: 532-541

16 毛景文, 张作衡, 余金杰, 等. 华北及邻区中生代大规模成矿的地球动力学背景: 从金属矿床年龄精测得到启示. 中国科学 D 辑: 地球科学, 2003, 33: 289-299

17 孙晓明, 刘孝善. 金堆城钼矿区两类不同花岗岩的关系及其成因研究. 地质找矿论丛, 1987, 2: 34-45

18 王长明, 邓军, 张寿庭, 等. 河南南泥湖 Mo-W-Cu-Pb-Zn-Ag-Au 成矿区内生成矿系统. 地质科技情报, 2006, 25: 47一 52

19 Stein H J, Markey R J, Morgan J W, et al. Highly precise and accurate Re-Os ages for molybdenum from the East Qinling molybdenum belt, Shannxi Province, China. Econ Geol, 1997, 98: 175-180

20 刘永春, 靳拥护, 班宜红, 等。东秦岭一大别山钼成矿带赋矿地层分布规律。中国钼业, 2007, 31: 13-17

21 卢欣祥, 于在平, 冯有利, 等. 东秦岭深源浅成型花岗岩的成矿作用及地质构造背景. 矿床地质, 2002, 21: 168一178

22 刘孝善, 孙晓明. 金堆城钼矿成矿流体包裹体及稳定同位素研究. 地质与勘探, 1989, 25: 12-19

23 胡受奚, 林潜龙, 陈泽铭, 等. 华北与华南古板块拼合带地质和成矿. 南京: 南京大学出版社, 1988. 442-489

24 徐兆文, 杨㭉勇, 刘红樱, 等. 陕西金堆城斑岩钼矿床成矿流体研究。高校地质学报, 1998, 4: 423-431

25 张正伟, 朱炳泉, 常向阳, 等. 东秦岭钼矿带成岩成矿背景及时空统一性. 高校地质学报, 2001, 7: 307一 315

26 李永峰, 毛景文, 胡华斌, 等. 东秦岭钼矿类型、特征、成矿时代及其地球动力学背景. 矿床地质, 2005, 24: 292-301

27 安三元, 卢欣祥. 秦岭斑岩组合的地质特征及成矿关系. 见: 徐克勤, 涂光炽, 主编. 花岗岩地质和成矿关系. 南京: 江苏科 学技术出版社, 1984. 398-405

28 胡志宏, 胡受奚, 周顺之. 东秦岭燕山期大陆内部挤压-俯冲背景的 A 型孪生花岗岩带. 岩石学报, 1990, 1: 1一 12

29 李英, 任崔锁. 华北地台南缘铅同位素演化. 西安地质学院学报, 1990, 13: 1-12

30 郡克忠. 祁雨沟地区爆破角砾岩型金矿成矿条件和找矿方向研究. 河北地质学院学报, 1992, 15: 105-195

31 崔毫. 华北地台南缘(河南)有色、贵金属矿床铅同位素组成特征及成矿意义. 矿产与勘查, 1991, 2: 30-41

32 范宏瑞, 谢奕汉, 赵瑞, 等. 豫西熊耳山地区岩石和金矿床稳定同位素地球化学研究. 地质找矿论丛, 1994, 9: 54一63

33 何建坤, 刘富田, 刘建华, 等. 东秦岭造山带莫霍面展布与碰撞造山带深部过程的关系。地球物理学报, 1998, 41(增刊: 64-76

34 陈衍景, 倪培, 范宏瑞, 等. 不同类型热液金矿系统的流体包裹体特征。岩石学报, 2007, 23: 2085-2108

35 翟裕生, 邓军, 汤中立. 古陆边缘成矿系统. 北京: 地质出版社, 2002. 384

36 Ballentine C J, Burgess R, Marry B. Tracing fluid origin,transport and interaction in the crust, Collection in Noble Gases in Geochemistry and Cosmochemistry. Rev Mineral Geochem, 2002, 47: 539-614 [doi]

37 Ballentine C J, Burnard P G. Production, release and transportof noble gases in the continental crust. Rev Mineral Geochem, 2002, 47: 481-538[doi] 
38 Burnard P G, Polya D A. Importance of mantle derived fluids during granite associated hydrothermal circulation:He and Ar isotopes of ore minerals from Panasqueira. Geochim Cosmochim Acta, 2004, 68: 1607-1615 [doi]

39 Burnard P G, Hu R, Turner G, et al. Mantle, crustal and atmospheric noble gases in Ailaoshan Gold deposits, Yunnan Province, China. Geochim Cosmochim Acta, 1999, 63: 1595-1604[doi]

40 Dunai T J, Baur H. Helium, neon, argon systematic of the European subcontinental mantle: implications for its geochemical evolution. Geochim Cosmochim Acta, 1995, 59: 2767-2783[doi]

41 Graham D W. Noble gas isotope geochemistry of mid-ocean ridge and ocean island basalts: Characterization of mantle source reservoirs. Rev Mineral Geochem, 2002, 47: 247-317[doi]

42 Kendrick M A, Burgess R, Pattrick R A D, et al. Fluid inclusion noble gas and halogen evidence on the origin of Cu porphyry mineralizing fluids. Geochim Cosmochim Acta, 2001, 65: 2651-2668[doi]

43 Mamyrin B A, Tolskhin I N. Helium Isotopes in the Nature. Amsterdam: Elsevier, 1984. 237

44 孙晓明, 徐莉, 梁金龙, 等. CCSD 中 HP-UHP 岩石稀有气体同位素地球化学及其对板块折返过程的示踪意义. 地质学报, 2006, 80: 1911 -1918

45 王登红, 余金杰, 杨建民, 等. 中国新生代成矿作用的惰性气体同位素研究与动力学背景. 矿床地质, 2002, 21: 179一186

46 Hu R Z, Burnard P G, Turner G, et al. Helium and argon isotope systematics in fluid inclusions of Machangqing copper deposit in west Yunnan province, China. Chem Geol, 1998, 146: 55-63[doi]

47 Hu R Z, Burnard P G, Bi X W, et al. Helium and argon isotope geochemistry of alkaline intrusion-associated gold and copper deposits along the Red River - Jinshajiang fault belt, SW China. Chem Geol, 2004, 203: 305-317 [doi]

48 胡瑞忠, 毕献武, Turner G, 等. 云南马厂箐铜矿床氦同位素组成研究. 科学通报, 1997, 42: 1542-1545

49 胡瑞忠, 毕献武, Turner G, 等. 哀牢山金矿带成矿流体氮、昰同位素地球化学. 中国科学 D 辑: 地球科学, 1999, 29: 321 一 330

50 胡瑞忠, 钟宏, 叶造军, 等. 金顶超大型铅、锌矿床氦、氩同位素地球化学. 中国科学 D 辑: 地球科学, 1998, 28: 208一-213

51 孙晓明, Norman D I, 孙凯, 等. 奥中长坑金银矿成矿流体 $\mathrm{N}_{2}-\mathrm{Ar}-\mathrm{He}$ 示踪体系及来源. 中国科学 D 辑: 地球科学, 1999, 29: 240-246

52 Sun X M, Wang M, Xue T, et al. He-Ar isotopic systematics of fluid inclusions in pyrites from PGE-polymetallic deposits in Lower Cambrian black rock series, Southern China. Acta Geol Sin, 2004, 78: 471-475

53 Moreir M, Blusztajn J, Curtice J, et al. He and Ne isotopes in oceanic crust: Implications for noble gas recycling in the mantle. Earth Planet Sci Lett, 2003, 216: 635- 643[ [doi]

54 Nicole A S, Samuel N, Karsten M H. Neon and helium isotopes as tracers of mantle reservoirs and mantle dynamics. Earth Planet Sci Lett, 2007, 258: 334-344[doi]

55 Polya D A, Foxford K A, Stuart F, et al. Evolution and paragenetic context of low $\delta$ D hydrothermal fluids from the Panasqueira WSn deposit, Portugal: New evidence from microthermometric, stable isotope, noble gas and halogen analyses of primary fluid inclusions. Geochim Cosmochim Acta, 2000, 64: 3357-3371 [doi]

56 Li X F, Mao J W, Wang C Z, et al. The Daduhe gold field at the eastern margin of the Tibetan Plateau: He, Ar, S, O, and H isotopic data and their metallogenic implications. Ore Geol Rev, 2007, 30: 244-256[doi]

57 Mao J W, Kerrich R, Li H Y, et al. High ${ }^{3} \mathrm{He} /{ }^{4} \mathrm{He}$ ratos in the Wangu gold deposit, Hunan Province, China: implications for mantle fluid along the Tanlu deep faultzone. Geochem J, 2002, 36: 197-208

58 Simmons S F, Sawkins F J, Schlutter D J. Mantle-derived helium in two Peruvian hydrothermal ore deposits. Nature, 1987, 329: 429-432[doi]

59 Stuart F M, Burnard P G, Taylor R P, et al. Resolving mantle andcrustal contributions to ancient hydrothermal fluids: He-Ar isotopes in fluid inclusions from DaeHwa W-Mo mineralisation, South Korea. Geochim Cosmochim Acta, 1995, 59: 4663 - 4673[doi]

60 Stuart F M, Turner G. The abundance and isotopic composition of the noble gases in ancient fluids. Chem Geol, 1992, 101: 97-109

61 薛春纪, 陈艈川, 王登红, 等. 滇西北金顶和白种坪矿床: 地质和 $\mathrm{He}, \mathrm{Ne}, \mathrm{Xe}$ 同位素组成及成矿时代. 中国科学 D 辑: 地球科学, 2003, 33: $315-322$

62 Tongerson T, Kennedy B M, Hiyagon H. Argon accumulation and the crustal degassing flux of Ar in the Great Artesian Basin, Australia. Earth Planet Sci Lett, 1988, 92: 43-59

63 张连昌, 沈远超, 李厚民，等. 胶东地区金矿床流体包裹体的 He、Ar 同位素组成及成矿流体来源示踪. 岩石学报, 2002, 18: 559-565

64 赵葵东，蒋少涌，肖红权. 大厂锡-多金属矿床成矿流体来源的 He 同位素证据. 科学通报, 2002, 47: 632-635

65 Tosdal R M, Cline J S, Mark F C, et al. Lead in the Getchell-Turquoise Ridge Carlin-Type Gold Deposits from the perspective of potential igneous and sedimentary rock sources in Northern Nevada: Implications for fluid and metal sources. Econ Geol, 2003, 98: 1189-1211[doi]

66 赵太平. 华北陆块南缘元古宙熊耳群钾质火山岩特征与成因. 博士学位论文. 北京: 中国科学院地质地球物理研究所. 2000.1 - 102

67 Zartman R E, Doe B R. Plumbotectonics —The model. Tectonophysics, 1981, 75: 135 -142[doi]

68 张宏飞, 靳兰兰, 张利, 等. 西秦岭花岗岩类地球化学和 Pb-Sr-Nd 同位素组成对基底性质及其构造属性的限制. 中国科学 D 辑: 地球 科学, 2005, 35: 914-926

69 徐九华, 谢玉玲, 王丽君, 等. 地幔矿物中 $\mathrm{CO}_{2}$ 流体包裹体的微量元素特征. 岩石学报, 2003, 19: 307-313

70 任纪舜, 陈廷愚, 牛宝贵, 等. 中国东部及邻区大陆岩石圈的构造演化与成矿. 北京: 科学出版社, 1992. 1-230

71 邓晋福, 莫宣学, 赵海玲, 等. 中国东部岩石圈根一一去根作用与大陆“活化”. 现代地质, 1994, 8: 349-356

72 袁学诚. 秦岭岩石圈速度结构与蘑菇云构造模型. 中国科学 D 辑: 地球科学, 1996, 26: 209-215

73 金昕, 任光辉, 曾建华, 等. 东秦岭造山带岩石圈热结构及断面模型. 中国科学 D 辑: 地球科学, 1996, 26(增刊): 13-22 